\title{
多軸力センサと产の応用:
}

Multi-Axis Force Sensors and their Applioations

Key words: force sensor, parallel plate structure, radial plate structure, 6-axis force sensor, torque-thrust sensor, force control system, intelligent manufacturing

\section{1. 多軸カセンサ}

$\mathrm{x}, \mathrm{y}, \mathrm{z}$ の 3 軸方向の力や 3 軸回りのモーメントをそ れぞれの成分に分離して検出する多軸力センサは, 従 来から力学現象の解明に用いられてきた. 一方近年に なって, ロボット, 加工機械, 建設機械などの力制 御, 作業状況の把握, 遠隔操作などです多軸力センサ の必要性が高まってきた。これは，例えば，力による 加工に拈いては図1に示す通り,工具と被加工物 (ワーク）との間に作用している力は方向についても 位置についてる本質的に 3 次元的であり，そこで作用 している力の位置や大きさを知ろらとするには, 工具 側から検出するにせよ, ワーク側から検出するにせ よ, 本来, 3 軸方向の力の各成分と 3 軸回りのモーメ ントの各成分, 合計 6 成分を検出しなければ, 事実を 把握することがでさないからである．別の言い方をす れば, 工具側からであれ，ワーク側からであれ，加工 で生じている 3 分力と 3 モーメントが検出できれば, 加工で生じている力の大きさや方向が分かるだけでな く，その力の作用点まで実時間で検知できるからであ る.

さて，このような目的に使用される多軸力センサに は実に多くのことがらが要求される.すなわち，(i) カやモーメントの各成分が他成分の干渉なく検出でき ること, (ii) 剛性・固有振動数が高く, センサを挿入

* 原稿受付 平成 3 年 7 月 22 日

** 正 会 員 東京大学工学部 (東京都文京区本郷 7-3-1)
したことで系の力学特性ができるだけ変わらないこ と,（iii）十分な感度を持つこと，(iv）センサ自体が 運動部分に取り付けられることが多いので, 軽量でュ ンパクトなこと,（v）長期安定性・耐環境性に優れる こと, (vi) コストが安く信頼性が高いこと,などで ある.

このような多くの要求を満たすセンサとして, 筆者 らは図 2 に示す平行平板構造と放射平板構造を持つ力 センサの研究・開発を行ってきた. その多くは，これ らの構造にひずみゲージを組み合わせたものである.

いずれも可動部と固定部とを 2 枚の薄板で結んだ構造 であり, カやモーメントによって両薄板の表面に直交 する方向に生じる力によってその方向にのみ変形し， 薄板の両端の根元表面には引張りおよび圧縮のひずみ が生じる.このひずみは 2 枚の薄板の根元の合計 4 か

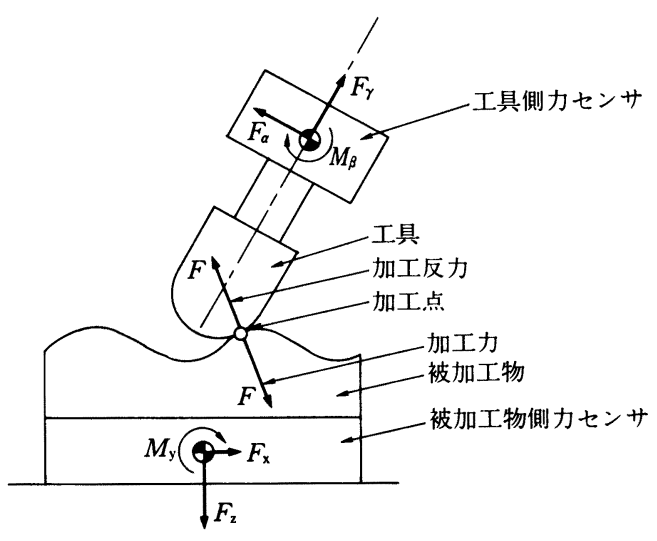

図 1 加工と多軸力センサ 


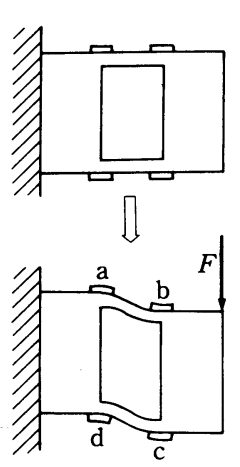

(a) 平行平板構 造による力 の検出

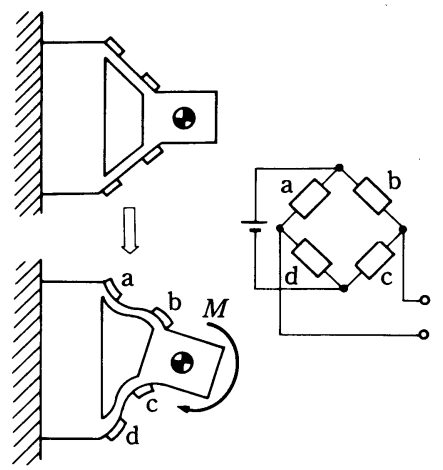

(b) 放射平板構 造によるモ ーメントの 検出 (c) Uずみゲー ジによるブ リッジ回路

図 2 平行平板と放射平板による力とモーメントの検出

所に貼り付けられたひずみゲージで電気抵抗に変換さ れ，ブリッジ回路で電圧に変換される．このようにし て平行平板構造は 1 軸方向の力を, 放射平板構造は 1 軸回りのモーメントを，他の力やモーメント成分の干 渉を受けずに検出することができる.これらの構造 は, 上述の (i) （vi）の諸要求を満たすほかに (i) 構 造の重ね合わせにより，任意の多軸力センサを容易に 構成することがでさること，(ii）ひずみゲージ以外の 他の変換素子やピェゾ素子などの能動素子との組合せ が可能であること，等の特徵を持っている.

図 2 に示した平行平板構造および放射平板構造はそ の要求される条件に応じて対称化，回転，ねじり，ひ

きのばしなどの思考演算により図 3 の (a), (b) に示 すよらな様々な展開が可能である。 また，それらの組 合せは同図 (c) に示すように, 必要な力やモ゙ーメント の成分に応じて種々のものが可能である.

\section{2. 平行平板構造}

平行平板構造を用いたカセンサの設計について考え る.

平行平板構造は図 2 (a) に示した主な変形（これを “1 次変形”之呼ぶ）のほかにも他の力やモーメント の成分（これを総称して単に“力成分”之呼ぶ）に よって, 図 4 に示すように様々の副次的な変形（これ らを“2 次変形”之呼ぶ）を生じる. 2 次変形で生し る表面ひずみおよび変位は, 通常は 1 次変形によるそ れらより小さいので，力センサの概略設計においては それらを無視することができる，なお，詳細な設計お よび 1 つの平行平板構造で多くの力成分を検出したい ときには，これらの変形を考虑に入れる必要がある.

平行平板構造を用いた力センサの設計に用いる1次 変形の計算式を図 5 に示す，例光ば，S 45 C（調質 材）の $20 \mathrm{~mm}$ の角棒に端部から $5 \mathrm{~mm}$ のところに $l=1 \mathrm{~mm}, t=0.35 \mathrm{~mm}$ になるよらにワイヤカットで 角穴をあけ，薄板の根元にひずみゲージを貼ってカセ ンサを作ると, 定格荷重 $10 \mathrm{kgf}(98 \mathrm{~N}$ ) の場合, $\delta=0.28 \mu \mathrm{m}, \varepsilon=290 \times 10^{-6}$, $k=36 \mathrm{kgf}(353 \mathrm{~N}) / \mu \mathrm{m}, f=754 \mathrm{~Hz}$
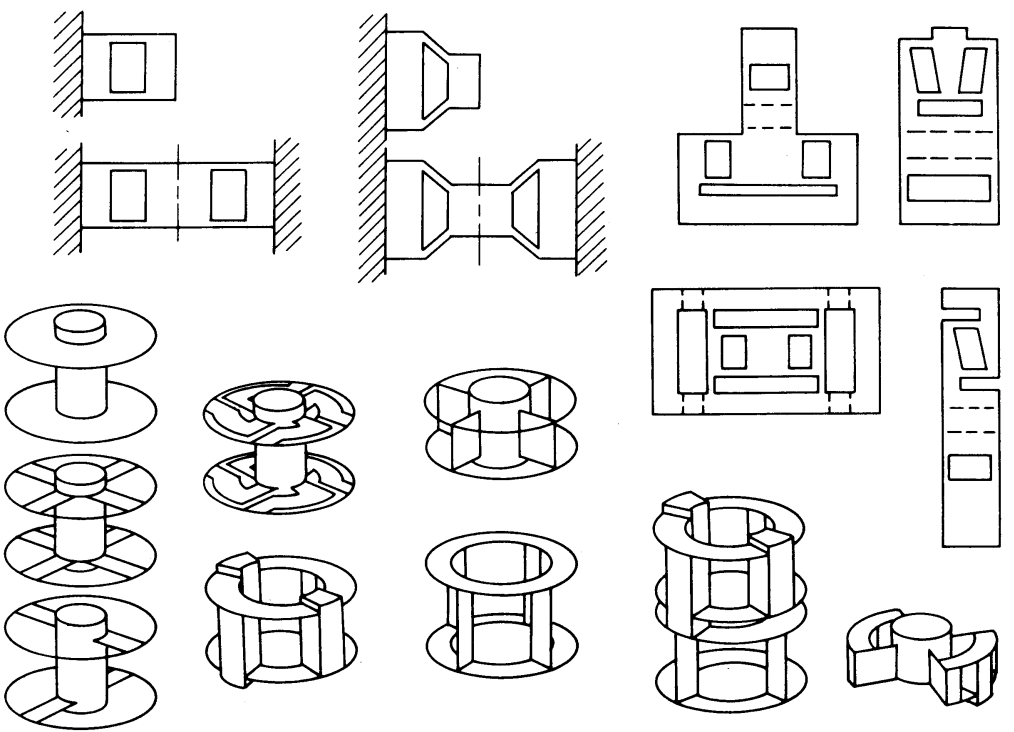

(a) 平行平板構造

(b) 放射平板構造

(c) それらの組合せ

图 3 平行平板構造之放射平板構造の展開 


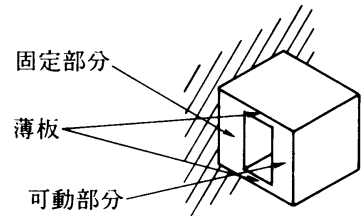

(a) 構 造
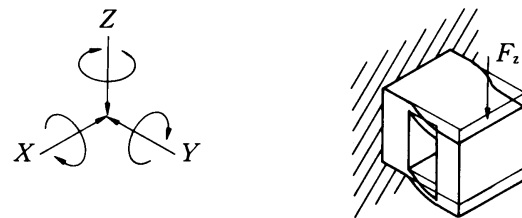

(b) 一次変形

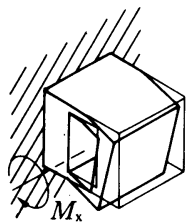

(c-1)

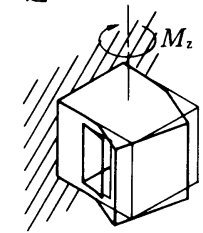

(c-2)

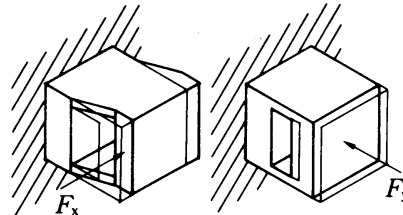

(c-3) $(\mathrm{c}-4)$

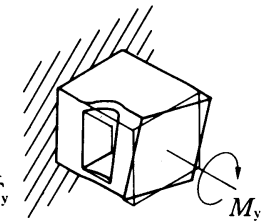

(c-5)

(c) 二次変形

図 4 平行平板構造の種々の変形

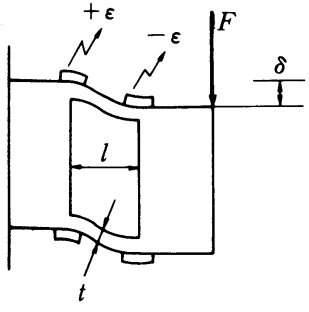

幅: $b$

可動部質量 : $m$

䛧弾性係数: $E$

$$
\text { たわみ } \delta=\frac{F l^{3}}{2 E b t^{3}}
$$$$
\text { 根元のひずみ } \varepsilon=\frac{3 F l}{2 E b t^{2}}
$$$$
\text { 㓮性 } K=\frac{2 E b t^{3}}{l^{3}}
$$

固有振動数 $f=\frac{1}{2 \pi} \sqrt{\frac{2 E b t^{3}}{m l^{3}}}$

図 5 平行平板構造によるカセンサの設計

となる。これを実際に作ってみると，種々の簡略化や 製作誤差にもかかわらず, 出力 (約 $4 \varepsilon$ ), 剛性, 固有 振動数とも，この簡略計算の約 $80 \%$ 程度のものが得 られ，平行平板構造の性能が優れていることが分か る.

平行平板構造はこのよらに多軸力センサの構成のし やすさと優れた特性とを持っているが，実際の製作 上，角穴が作りにくい場合や，ひずみゲージを外部に 露出させたくない場合，さらに高い比出力（単位変位 量当たりの出力）が欲しい場合などが生じることがあ る.そのようなときには，図6に示すように角穴を丸 穴にしたり，単穴を多穴にしたり，平行平板構造とせ ん断板とを並用するなどの工夫を採用することができ る.

\section{3. 多軸カセンサとその応用システム}

筆者らは平行平板構造, 放射平板構造を用いた力セ ンサを多数試作・開発を行ってきたが，主なるのの構 造とその応用システムを紹介する.

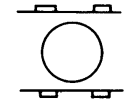

(a) 丸穴

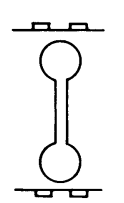

(b) 連結丸穴

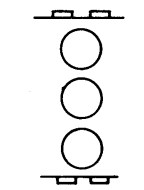

(c) 多穴丸穴

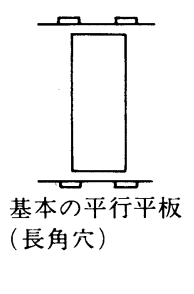

基本の平行平板

穴

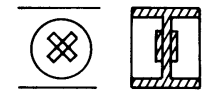

(e) せん断板付 丸穴

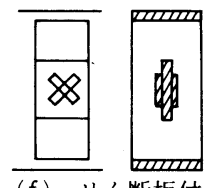

(f) せん断板付 長角穴
図 6 平行平板構造の種々のバリエーション

1) ロボット用 6 軸力計 $^{1) ~ 3) ~}$

プロトタイプの検出ブロックの構造を図 7 に示 $す^{11}$. ここでは平行平板構造と放射平板構造との 1 次 変形モードのみで検出しているが，構造が複雑で大き くなり過ぎる欠点があった. 現在市販されている実用 タイプでは平行平板構造の 2 次変形モードを用い, そ れを 2 段に重ねただけの構造で 6 軸力を検出してお り，特に力制御ロボットのシステムに広く使用されて いる.これを用いれば例光ば自動バリ取りロボットや 金型の自動研削システムなどを構成することができ る.

\section{2) リング状 6 軸力計4)}

上記のものと同じ目的に使用されるものであるが， 検出部全体が図 8 に示すようにりング状になってお り, 加工工具を中心部に配置することができるので, 


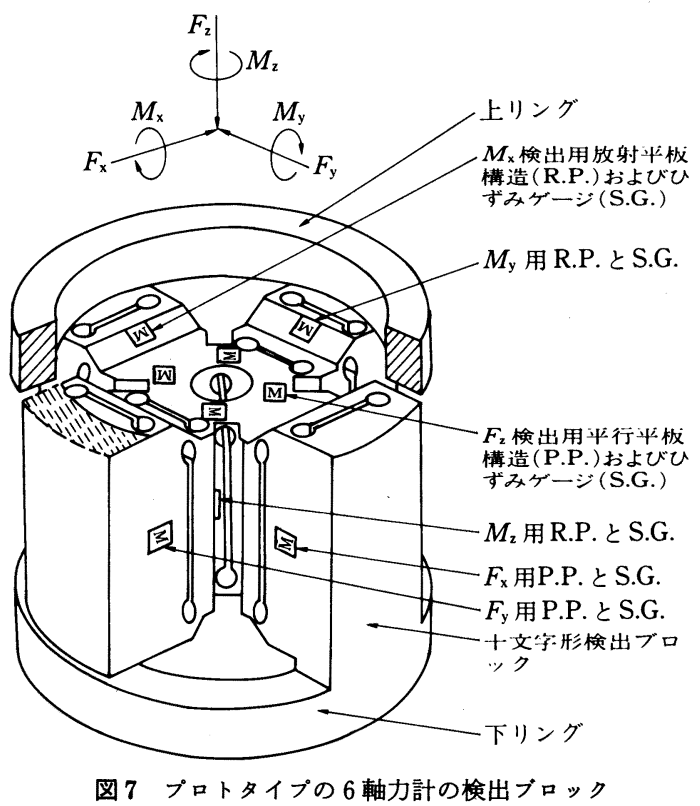

カによるモーメント検出性能への干渉を少なくするこ とができる．金型の自動研削などへの適用が試されて いる.

3）ドリル用トルク・スラスト検出ホルダ

この検出器の構造を図 9 に示す4)5). 検出器は回転 する工具ホルダの内部に配置した支承部之変換部とか ら成り, 図 3 (c) 左に示した平行平板と放射平板の組 合せで中心軸を支光，その軸にねじれと軸方向の変位 を生じさせる，それらの変位量を同図 (c) 右の検出ブ

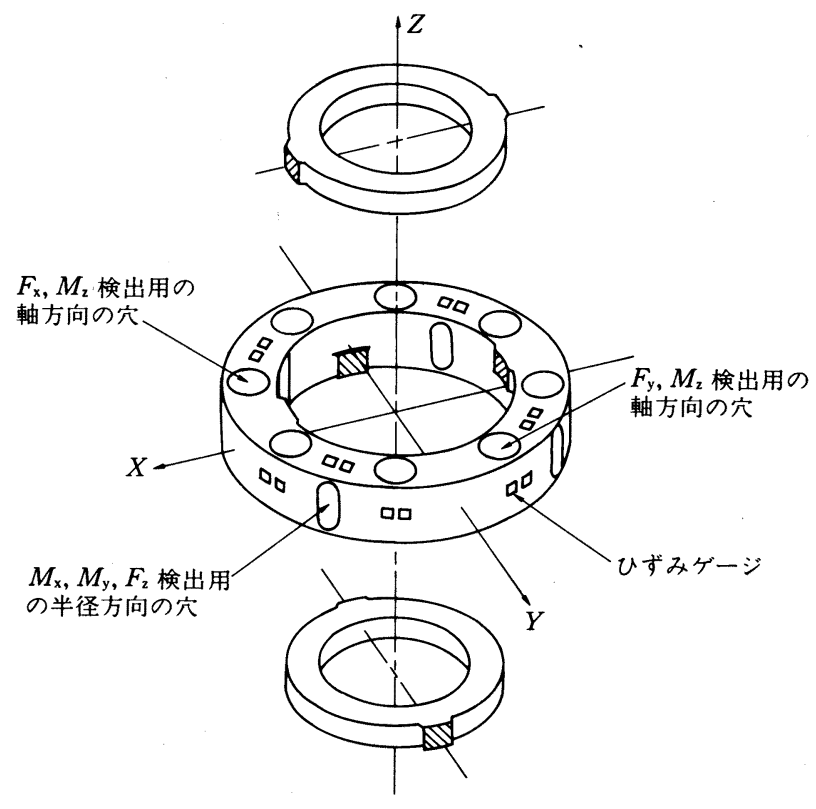

図 8 リング状 6 軸力計の基本構造
ロックで検出することにより，トルクとスラストをそ れぞれ独立に検出するすのである. その出力はFM 送受信機を用いて回転系から静止系に送信される。こ れを用いドリルの折損についての知識を集約し，それ を制御システムに取り込むことで，小径ドリルの折損 検知予知システムを作ることができる.

4) バイトセンサ

旋削用のバイトをセンサ化したものである．3 分力 検出ホルダの例を図 10 に示す6). この例では， 3 分力 をそれぞれ別々の平行平板構造で検出しているが，平 行平板の 2 次変形（図 4) やバリエーション（図6) を用い, 1 個の平行平板構造で 3 分力を検出するるの も作ることができ，単純な形で高剛性のものが得られ る7)。またこれらの 3 分力の知識を用い，平行平板構 造の主分力計で旋削状態を全自動モニタするシステ ム8) あ作ることができる。

5） 6 分力検出テーブル9110)

加工中に被加工物にかかる 6 軸力を検出するもので ある. プロトタイプの検出ブロックの構造を図 11 に 示す9). 被加工物の取り付けられる上部ブロックは4 個の平行平板構造の 3 軸力検出ブロックで支えられて おり，それらからの 12 個の出力から計算により 6 輔 力が算出されるすのである. このセンサを用いるとマ シニングセンタでの切削情報の自動収集システムを作 ることがでさ，それによって得られた知識をもとに加 工の知能化システムの構筑が可能になるものと考光ら れる.

6）ピン形ロードセル

建設機械などの大形作業機械のリンクの関節 部には回転ピンが多用されるが，そのピンの両 端部にかかるそれぞれ2 方向の力を検出するも のである．その一例を図 12 に示す ${ }^{11}$ ．通常数 $\mathrm{tf}$ から数十 $\mathrm{tf}\left(10^{4} \sim 10^{6} \mathrm{~N}\right)$ あの大きな力のか かるピンの端部のせん断変形分だけをピン内新 に配置した 2 段重ねの平行平板構造で 2 方向に 分離して検出することができる，現在までのと ころ 1 個のピンで最大 $500 \mathrm{tf}\left(4.9 \times 10^{6} \mathrm{~N}\right)$ で検出できるものを試している，これを用いる と建設作業中に生じる異常検知や転倒防止な早 のシステムを構筑することができる.

7）磁気ディスク用ヘッドセンサ

磁気ディスクとへッドの間に働く力を検出才 るものである. 図 13 にこの目的に使 55 分力 計の構造の例を示す ${ }^{12)}$. この例では 2 段に重邚 た平行平板構造に放射平板構造を重ねたるの ある.ヘッドがディスク表面上に接して停止 


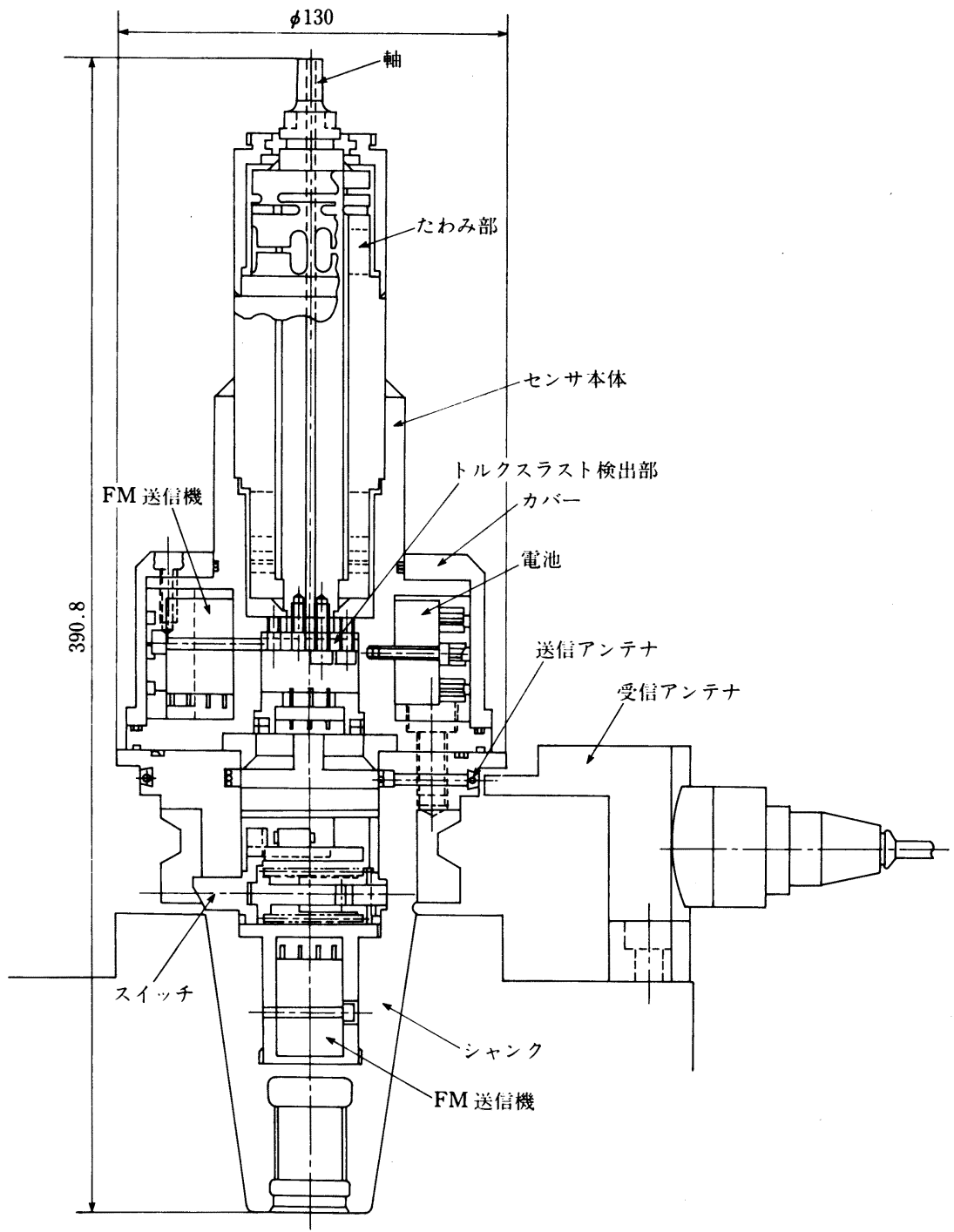

図9 小径ドリル用トルクスラスト検出ホルダの構造

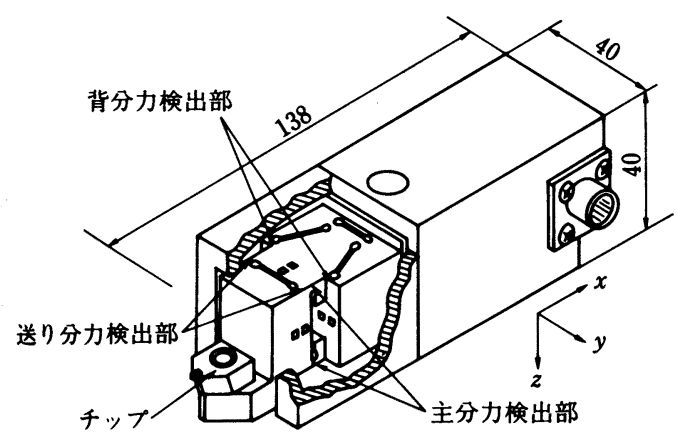

図 103 分力検出ホルダ

た状態から、ディスクの回転とともに浮上し，最後に での 5 軸力を検出することができる．これらの 5 軸力 のらち最も重要なのはディスク回転方向の摩擦力の検 出であり, 今後, 浮上高さを小さくするための表面構 造と潤滑剤の開発にはこの摩擦力のみを検出する高性 能の 1 軸力センサの開発が望まれる.

筆者らは上に紹介したカセンサのほかにも，金型セ ンサ13), ナノロボット用主分力計 ${ }^{14)}$ ，マイクロテス ティング用 2 方向カセンサ, 積層基板圧着用圧力分布 計 ${ }^{15)}$, 七ラミックス成形用壁面応力計 ${ }^{16)}$, 粉粒体用壁 面応力計 ${ }^{17)}$ などの多分力計の開発を試みているが， ここでは紙面の都合上割愛する.

回転が止まってヘッドがディスク表面上に停止するま 


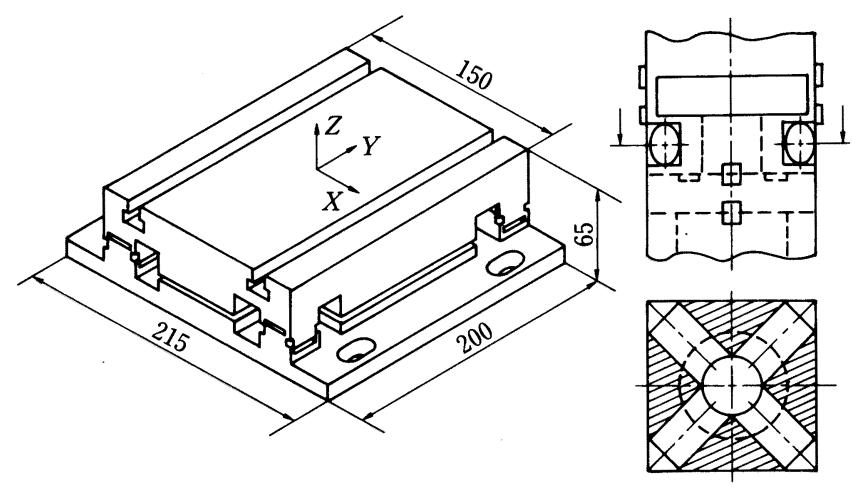

定格: $F_{X}, F_{Y} 1000 \mathrm{~N}, F_{Z} 2000 \mathrm{~N}, M_{X}, M_{Y} 200 \mathrm{~N} \cdot \mathrm{m}$, $M_{Z} 100 \mathrm{~N} \cdot \mathrm{m}$

固有振動数: $f_{X}, f_{Y} 1.05 \mathrm{kHz}, f_{Z} 1.48 \mathrm{kHz}$

㓮性 : $k_{X}, k_{Y} 185 \mathrm{~N} / \mu \mathrm{m}, k_{z} 360 \mathrm{~N} / \mu \mathrm{m}$

図 116 分力検出テーブル

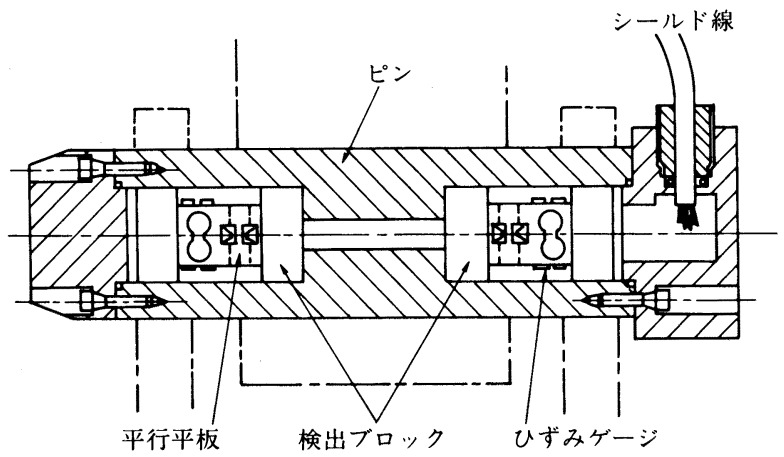

直径: $\phi 50 \mathrm{~mm}$, 長さ $390 \mathrm{~mm}$, 重量 $8.26 \mathrm{~kg}$, 定格荷重 $100 \mathrm{kN}$, 定格出力 $1500 \times 10^{-6}$ strain

図 12 ピン形ロードセルの構造

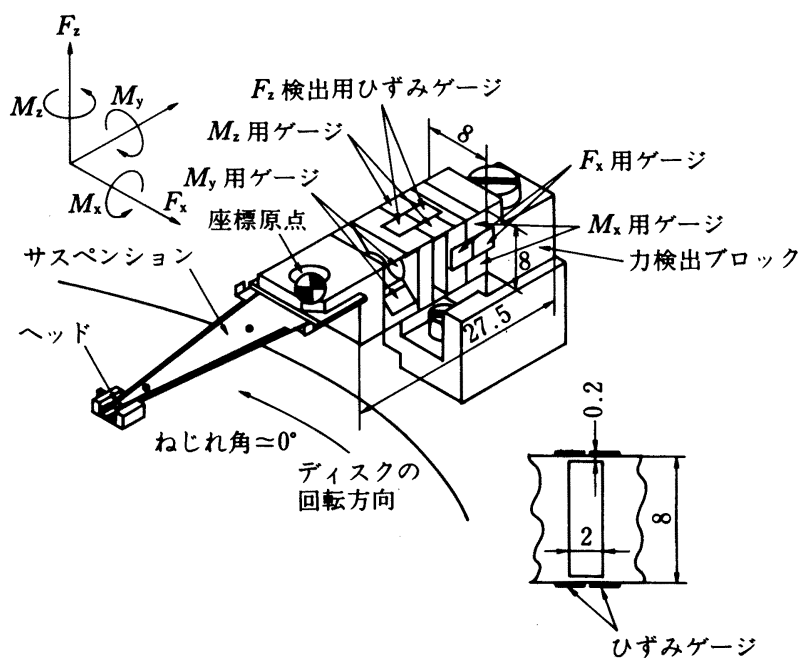

定格 : $500 \mathrm{mN}, 15 \mathrm{mN} \cdot \mathrm{m}$

用性: $1.1 \mathrm{~N} / \mu \mathrm{m}$, 固有振動数 $>2.8 \mathrm{kHz}$

図 13 磁気ディスクヘッド用 5 軸力センサ

\section{4. 今後 の 発 展}

上述のように平行平板構造と放射平板構造 とから始まった多軸力センサの開発で得た多 くの経験から次第に次のような考光，すなわ ち, (1) 平行平板構造の 2 次変形の利用, （2）カセンサから能動素子への転換, (3) 加 工の知能化に用いる知能化素子の開発，とい ら考えを得るよらになった。

1) 平行平板構造の 2 次変形の利用

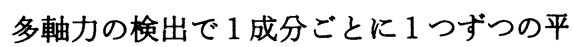
行平板構造や放射平板構造を用いると互いの 干渉を小さくするには効果があるが，図 7 の

例に示すよ5に全体が大きく，重くなり，加 工が困難な上に全体の剛性が落ちる欠点が生じ る.これらの欠点を解決するには図 4 に示した平 行平板構造の 2 次変形と図 6 に示した平行平板構 造の種々のバリエーションを利用するのが得策で ある. 特にロボット用のよ5に軽量・小形を要求 される場合や，加工機械用のように高剛性を必要 とする場合に有効であり, 今後の多軸力センサで はこれらの構造とひずみゲージの組合せが発展す るあのと考えられる.

2）力センサから能動素子へ

カセンサはカを受けて情報を発生するるのであ り, 力や変位の側面からみると受動的 (パッシ ブ）な素子である.これを逆転し，情報を受ける と力や変位を発生する素子が能動的（アクティ ブ）な素子である. 現在微小な変位を発生する素 子として積層圧電素子が広く用いられ始めている が，これには非線形性と履歴性の 2 つの欠点が付 随している. この問題を解決し，見かけ上完全な 線形性を持つ微動素子が図 14 に示す “平行平板 構造による微動素子”である. 平行平板構造の間 に配置された压電素子によって上ブロックが変位 しその変位量を平行平板の根元に貼り付けられた ひずみゲージで検出し、フィードバック回路を用 いて目標とする変位を発生させるものである. 力 センサの時と同じく，この素子を重ね合わせるこ とで任意の多軸アクチニエータを容易に構成する ことができ, 種々の微細位置決め装置 ${ }^{18)}$, ナノ口 ボット ${ }^{14)}$, マイクロテスティングシステム, など に用いられている.

3）加工の知能化と知能化素子

現在生じている加工現象からセンサを通じて触 


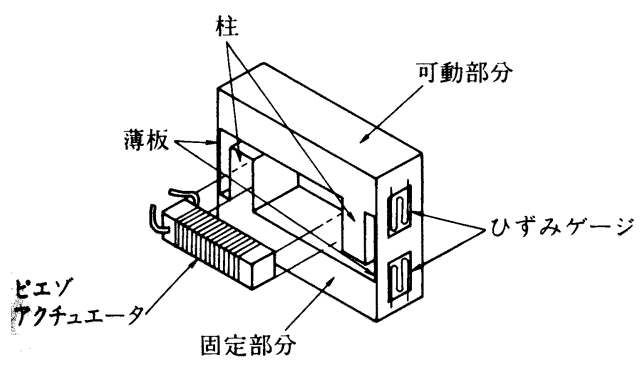

(a) 構 造

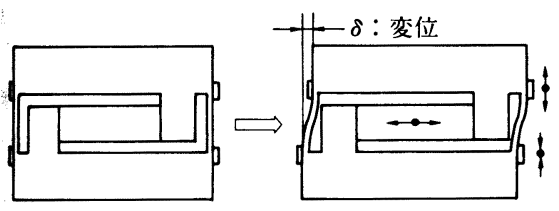

(b) 変 形

図 14 ナノメータ変位の発生機構とその変形

政取り込み，あらかじめ用意してある知識に当ては めて近未来の状態などの所要の情報を作り，それに よってアクチュエータを通じて現象そのものを制御す る “加工の知能化”19) ではセンサとアクチュエータと が一体となった素子である“知能化素子”が必要にな ๖. 現在のところ, 筆者らは超精密旋削用の知能化素 子の開発を行っている ${ }^{20)}$. これは主分力センサと，切 汉方向の微細送り機構とが一体化されたもので，薄 内感光ドラムの切削などで所期の機能を発揮してい る.

以上，筆者らの行っている多軸力センサの研究，開 然とその基本的な考え方を紹介した. 今後ともこの方 向はますます発展するものと考えられ，拙文が読者の こ台考になれば幸いである。

\section{考文献}

1）㚼村洋太郎, 饭野謙次, 小野耕三, 高田龍二：ロボット 用 6 軸力計の試み，日本機械学会論文集， 54, 497 (1988) 241 .

2) K. Ono and Y. Hatamura: A New Design for 6component Force/Torque Sensors, 11th Int. Conf. Measurement of Force and Mass, IMEKO, Amsterdam, (1986) 39.

3) Y. Hatamura, K. Matsumoto and H. Morishita : A Miniature 6-axis Force Sensor of Multi-layer Parallel Plate Structure, Proc. IMEKO, Houston, USA, (1988) 621.

4) Y. Hatamura : A Ring Shape 6-axis Force Sensor and its Applications, The Int. Conf. Advanced Mechatronics, Tokyo, (1989) 647.

5) T. Nagao and Y. Hatamura : Investigation into Drilling Laminated Printed Circuit Board, Ann. CIRP, 37, 1,
(1988) 79 .

6）畑村洋太郎, 森下 広: 薄肉円筒切削時の 3 分力の測定 の試み，昭和 63 年度精密工学会春季大会学術講演会講演 論文集, (1988) 669 .

7）畑村洋太郎，足立光明：磁気ディスク切削用モノブロッ ク形 3 分力検出ホルダの試み, 1989 年度精密工学会秋季 大会学術講演会講演論文集, (1989) 255.

8）伊藤豊次, 㴧 雅夫, 稲城正高, 川田 尚, 橋本隆美, 畑村洋太郎, 足立光明：超精密切削における加工状態の インブロセス検出（第 1 報, 切削状態検出システムの開 発), 1991 年度精密工学会春季大会学術講演会講演論文 集;（1991） 255 .

9）畑村洋太郎, 長尾高明, 光石 衛, 高橋一敏, 一戸誠之, 西保木宏男 : 6 分力テーブルを用いたフレキシブル・マシ ニンクシステム (第一報, 6 分カテーブルの開発), 昭和 62 年度精密工学会秋季大会学術講演会講演論文集, (1987) 395

10）大庭孝志, 光石 衛, 畑村洋太郎, 長尾高明：加工の知 能化用実用形 6 分カテーブルの試作研究, 関東学生会第 29 回学生員卒業研究発表講演前刷集, (1990.3) 207.

11）畑村洋太郎, 高田龍二：ピン型ロードセルの開発，日本 機械学会論文集, 54, 497-C (1988) 234.

12) Y. Hatamura, M. Nakao, H. Miyazaki and T. Shinohara : A Measurement of Sliding Resistance Forces for Various Heads and Disks by High-rigid Force Sensor, IEEE Trans. Mag., 24, 6, (1988) 2638.

13）米山猛, 畑村洋太郎：金型センサの開発，日本機械学 会論文集, 52，481-C (1986) 2551.

14) Y. Hatamura and H. Morishita : Direct Coupling System between Nanometer World and Human World, Proc. IEEE, Micro Electro Mechanical Systems, Napa Valley, California, (1990) 203.

15) Y. Hatamura and K. Yamauchi : Analysis of the Dynamic Phenomena during Lamination of Multilayer Printed Circuit Board by the Measurement of Pressure Distribution, Japan Int. Electronic Manufacturing Technology Symp., Nara, Japan, (1989) 303.

16) Y. Hatamura and T. Mikami : 2-Directional Stress Measurement on Ceramic Forming in High Pressure, 1st Int. Conf. Measurement and Control of Granular Materials, Shenyang, (1988) 237.

17) Y. Hatamura and T. Takeuchi : A New Detecting Method of Granular Stresses Acting on Silo Wall, 1st Int. Conf. Measurement and Control of Granular Materials, Shenyang, (1988) 288.

18）烟村洋太郎, 小野耕三, 村山 健：平行平板・放射平板構 造を用いた多軸徽細位置決め機構，昭和 61 年度精密工学 会北海道地方講演会, (1986) 75 .

畑村洋太郎，小野耕三，長澤 淛，村山 健：平行平板・ 放射平板構造を用いた多軸微細位置決め機構, 昭和 62 年 度精密工学会春季大会学術講演会講演論文集, (1987) 495 .

19）畑村洋太郎：加工の知能化とその基本構成，1989年度精 密工学会秋季大会学術講演会講演論文集, (1989) 297.

20）畑村洋太郎, 足立光明：知能化切削の考光に基つく薄肉 感光ドラム切削の試み，1991 年度精密工学会春季大会学 術講演会講演論文集, (1991) 259. 